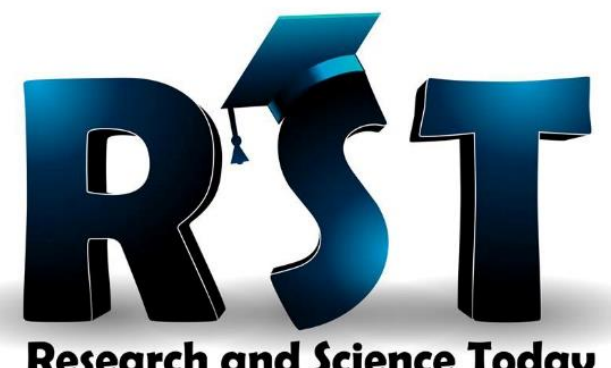

\title{
DOI:10.38173/RST.2020.20.2.6:65-77
}

Title:

\section{CONSIDERATIONS ON PREVENTING AND COMBATING THE}

TERRORIST PHENOMENON

Authors:

Cătălin PEPTAN

Adrian BUTNARIU

Section: INTERNATIONAL RELATIONS

Issue: $\quad 2(20) / 2020$

Received: 29 August 2020

Accepted: 18 September 2020
Revised: -

Available Online: 15 November 2020

Paper available online HERE 


\title{
CONSIDERATIONS ON PREVENTING AND COMBATING THE TERRORIST PHENOMENON
}

\author{
Cătălin PEPTAN ${ }^{1}$ \\ Adrian BUTNARIU ${ }^{2}$
}

\begin{abstract}
:
THE AUTHORS ADDRESS THE ISSUE OF PREVENTING AND COMBATING THE TERRORIST PHENOMENON, IN THE CONTEXT OF EXPANDING ITS MANIFESTATIONS GLOBALLY, AT THE SAME TIME THE PHENOMENON TURNED IT INTO ONE OF THE MOST DANGEROUS SECURITY THREATS. DUE TO ITS TRANSBOUNDARY NATURE, IN THE AUTHORS OPINION THE MEASURES TO BE TAKEN IN THE FIELD OF PREVENTION AND CONTROL MUST BE GLOBAL, AND THE ACTIONS TAKEN IN THIS REGARD MUST BE SUPPORTED BY BOTH INTERNATIONAL SECURITY ORGANIZATIONS AND STATE ENTITIES.

THE AUTHORS REVIEW THE CONCEPTUAL AND OPERATIONAL FRAMEWORK THAT CHARACTERIZES THE ACTIONS OF INTERNATIONAL AND EUROPEAN ORGANIZATIONS WITH RESPONSIBILITIES IN THE FIGHT AGAINST TERRORISM, HIGHLIGHTING THEIR ROLE AND NECESSITY, AS WELL AS THE OPERATIONAL SUCCESSES ACHIEVED.

AT THE END OF THE ARTICLE, IS BROUGHT IN THE DISCUSSION THE IMPORTANCE OF THE ACTION OF CIVIL SOCIETY IN ENSURING THE STABILITY OF THE SECURITY EQUATION AS A WHOLE, AS WELL AS IN THE CONCERTED ACTION AGAINST THE FORMS OF MANIFESTATION OF THE TERRORIST PHENOMENON.
\end{abstract}

KEYWORDS: SECURITY, TERRORISM, EUROPEAN ORGANIZATIONS, INTERNATIONAL ORGANIZATIONS

\section{GENERAL CONSIDERATIONS}

A complex phenomenon, widespread on a global scale, considered being one of the most destabilizing challenges to which humanity is subject, terrorism is a major danger facing today's society. The evolution of the terrorist phenomenon, from the beginning of the $21 \mathrm{st}$ century to the present, imposes the need of understanding its complexity, especially since its manifestations and implications have affected stability and social balance in more than one of the regions of the world.

In recent decades, terrorism has been a tool of terror used to inoculate fear and mistrust - which disregards origins, religion, age, sex, race, political appetite or intellectual orientation and a trigger for chaos and destabilization of public order. Fright, fear or terror,

\footnotetext{
${ }^{1}$ Lecturer PhD., „Constantin Brâncuși” University of Târgu-Jiu, e-mail: catalinpeptantm@ gmail.com;

${ }^{2}$ Legal advisor, e-mail: adrian.butnariu.tm@gmail.com;
} 
spread by terrorist acts, are of an unprecedented scale, their causality often exceeding the boundaries of human understanding, betraying the rational factor, this makes the emotional response of innocent people - potential victims, or of entities involved in combating the phenomenon, facing the uncertainty created. ${ }^{3}$ The inability of some state decision-makers to be aware of their unpredictable danger and, at the same time, by their reduced ability to react in such situations, due to ignorance and a poor security culture have amplified the effects of terrorist acts.

Assuming that the terrorist phenomenon has a complex, cross boundary nature, with a global vocation, the measures necessary to be adopted to prevent and counteract it can only be global, a unilateral approach to such a threat being, for the most part, doomed to failure. With this in mind, as possible must take actions order to stop the phenomenon. Without effective collaboration and cooperation, in preventing and combating the terrorist phenomenon, the chances of eliminating this scourge substantially reduce.

History, including recent history, has shown us countless times that without interstate collaboration and cooperation, even the most politically and military influential states cannot counteract the destructive effects of terrorism.

\section{LEVEL. \\ 2. PREVENTING AND COMBATING TERRORISM AT INTERNATIONAL}

\subsection{Measures taken at the level of the United Nations.}

Terrorism is not a relatively new concept, as it appeared in the public and specialized spheres long before the globalized world, in which we live today, was so interconnected and interdependent. Efforts to prevent and combat the terrorist phenomenon, undertaken at international level, began long before the establishment of the United Nations (UN), preoccupying the international community since 1937, when the League of Nations prepared a project for a convention ${ }^{4}$ aimed at prevention and punishment of terrorism.

Although this convention was not finalized or adopted, and the definition of terrorism did not concern terrorist acts against civilians, but rather those directed against the state, it served as a reference point for further discussions on this topic, when the UN and regional intergovernmental organizations have addressed the issue from a legal and political perspective.

Due to the structural architecture of the UN, there have been discrepancies in the harmonization between the relevant national legislation and the normative standards of this international counter-terrorism institution. The lack of agreement on a unitary definition of the term does not mean that the international community has not made progress in combating the terrorist phenomenon, with the UN and other international organizations succeeding in formulating ad hoc conventions on addressing its specific forms of manifestation. At the same time, UN has laid the foundations for the emergence of a variety of terminology in the field of terrorism, as evidenced by documents issued by the UN, its role being to provide guidelines to assist states in implementing measures requested by international institutions, namely creating appropriate legislative frameworks for the adoption of the most effective counter-terrorism measures.

\footnotetext{
${ }^{3}$ Cătălin, Peptan, Terrorism-Security threat in the context of globalization, Annals of the „Constantin Brâncuși” of Târgu-Jiu, Letter and Social Science, Series 1/2019, 126-142.

4 The draft convention defines terrorism as the totality of criminal acts directed against a state and has the intention or purpose of creating a state of terror in the perception of individuals, a group of persons or the public.
} 
Since 1963, with the increase in awareness of the terrorist phenomenon, the international community has developed multiple legal instruments (conventions, resolutions, etc.) aimed at preventing and combating international terrorism. ${ }^{5}$ Among the most important and recent being the International Convention for the Suppression of Acts of Nuclear Terrorism, of 14 September 2005, and Resolution no. 1904/2009 of the UN Security Council on the application of sanctions against Al Qaeda, Osama bin Laden and the Taliban groups. ${ }^{6}$

Following the terrorist attack ${ }^{7}$ on Lod Airport near the Israeli city of Tel Aviv, and the abduction and killing of 11 Israeli athletes during the 1972 Munich Olympics, the issue of terrorism has become the epicenter of attention at the UN General Assembly. Thus, by a note dated 8 September 1972, the Secretary-General, Kurt Waldheim, requested the General Assembly to include in the agenda of the seventh session an additional item of an important and urgent nature, entitled „Measures to prevent terrorism and other forms of violence that endanger human lives or endanger fundamental freedoms".

Compared to the organizational framework and internal rules of operation and decision-making, the work of the UN General Assembly reflects the global vision on the issue of terrorism in recent decades, distinguishing three different periods in terms of conceptual and action modalities. Thus, from 1972 to 1989, the approach to terrorism as a general issue attribute mainly to the Sixth Committee of the General Assembly, in a set of „Measures to Prevent International Terrorism”. At the time, there was a disagreement over how to act in preventing terrorism, with some members calling for international cooperation for suppressing terrorist acts, while others called for the need to eradicate the sources of this scourge. ${ }^{8}$

In the second period, between 1993 and 2001, basic approaches to terrorism focused on the development of measures to combat international terrorism, but with a focus on respect for human rights. The General Assembly issued numerous resolutions condemning acts of terrorism and calling on the Member States to cooperate in preventing and combating terrorism. However, there was no consensus among members of the Assembly on how to act to repress the terrorist phenomenon.

The terrorist attacks in 2001 against the USA, marked the beginning of the third stage, changing the orientation of the counter-terrorism policy in the General Assembly. The activity of this forum evolves towards the elaboration of concrete and effective measures to combat it, the starting point being the adoption of Resolution no. 1373/2001 of the UN Security Council on combating terrorism. At the same time, in the General Assembly there was a coagulation of opinions on future action, which contributed to the birth of numerous international conventions and protocols on terrorism, implemented by the Security Council, which are a key element in the global effort to combat terrorism. A document of exceptional significance in terms of actions to combat the terrorist phenomenon represents the Resolution no. 2178/2014. Through this resolution, UN imposed the adoption of cooperation measures at the level of the member state entities of this body, in order to adopt a pragmatic and effective response to the threats posed by the exponents of the terrorist groups.

\footnotetext{
5 Javier, Ruperez, The united nations in the fight against terrorism, 3-11, available at https://www.un.org/sc/ctc/wp-content/uploads/2017/01/2006_01_26_cted_lecture.pdf, accessed on 18.06.2020. ${ }^{6} \mathrm{https}: / / \mathrm{www}$. sri.ro/fisiere/studii/cadrullegislativ.pdf, accessed on 24.09.2020.

${ }^{7}$ On May 30, 1972, three members of the Japanese Red Army terrorist group recruited by the Popular Front for the Liberation of Palestine carried out an attack. The target was Lode Airport, the current Ben Gurian International Airport near Tel Aviv. Because of the attack, 26 people were killed and another 80 were injured.

${ }^{8}$ Ruperez, The united nations in the fight against terrorism..., 3-11.
} 
The UN Security Council has taken most of the responsibility for resolving the issue of global terrorism since the early 1990s, almost 10 years before the September 112001 terrorist attacks in the United States, by imposing sanctions and restrictions on states known to have terrorist organizations bases or camps on their territory.

In the context of the terrorist attacks of the late 1980s, which shook international public opinion, orchestrated by the dictatorial authorities in Libya ${ }^{9}$, in January 1992 the Security Council adopted Resolution 731 warning the Tripoli regime of the measures that will be taken if Libyan authorities will not proceed to hand over the suspects in the attacks. Afterwards, in March of the same year, the Security Council adopted Resolution no. 748, which cataloged the actions of the Libyan authorities as a threat to international peace and security, invoking the provisions of Chapter VII of the Charter of the United Nations in the application of a wide range of sanctions imposed on the Libyan state. ${ }^{10}$

Because of sanctions imposed by the Security Council, France obtained from Libya a partial fulfillment of its requests, and on September 12, 2003, after the Tripoli regime officially declared responsibility for the attacks and agreed to pay billions of dollars to the families of the victims as compensation, the Security Council lifted the sanctions imposed on Libya. ${ }^{11}$

Translating the issue to the last decades, a relevant example of the actions of the UN Security Council is the series of measures applied to Afghanistan, in the context in which the support given to the terrorist organization Al-Qaeda, led by Osama bin Laden, is well known. The Council adopted a considerable number of resolutions between 1999 and 2009, aimed at imposing sanctioning measures. These measures included freezing the funds of entities of individual or collective entities that commit, participate in or facilitate the commission of terrorist acts, the adoption of procedural standards for the listing of persons associated with Osama bin Laden and the Taliban regime. There were also travel restrictions imposed for persons associated with the terrorist group, embargo on the delivery of weapons to entities that could in any way support the terrorist group. ${ }^{12}$

Unfortunately, the complexity of the phenomenon and the relations created between the actors involved, including at state level, have made the measures imposed by the Council not always have the expected results. Being an institution with a strong political character, there were many situations in which its members did not reach a consensus on how to act.

\footnotetext{
9 In December 1988, Flight 103 Pan-Am crashed in Lockerbie, Scotland, following the explosion of an explosive device introduced on board of the aircraft. The 259 passengers on board and 11 people on the ground killed. See Pan Am Flight 103 explodes over Scotland, available at https://www.history.com/this-day-inhistory/pan-am-flight-103-explodes-over-scotland, accessed on 20.06.2020;

In September 1989, French flight UTA 772 crashed in Niger after an explosive device on board of the aircraft detonated and 171 people died. See Aviation Safety Network, available at https://aviationsafety.net/database/record.php?id=19890919-1, accessed on 20.06.2020.

10 See https://aviation-safety.net/database/record.php?id=19890919-1, accessed on 20.06.2020. In 1996, six Libyan nationals tried and convicted of participating in attacks on the UTA plane. The two Libyans, suspected of organizing the attacks on the Pan-Am flight, handed over to the Netherlands, on 5 January 1999, for trial by Scottish authorities in accordance with law. One of the defendants, Abdel Basset al-Megrahi, sentenced to life in prison in 2001 for life in a Scottish prison.

${ }^{11}$ https://aviation-safety.net/database/record.php?id=19890919-1,

${ }^{12}$ Ministry of Foreign Affairs, Sanctions regime against Osama Bin Laden, Al Qaeda, the Taliban and other terrorist groups, available at http://mae.ro/sites/default/files/file/userfiles/file/pdf/Sanctiuni\%20in \% 20vigoare / 2010_08_Al\% 20Qaeda,\% 20Usama\% 20bin\% 20Laden\% 20si\% 20Talibanii.pdf, accessed on 05.10.2020.
} 


\subsection{Measures taken at Interpol level.}

Contemporary terrorism characterizes by a multitude of forms of manifestation, in recent years manifesting its presence in conflict areas (especially in the Middle East and Central Asia) of the so-called ,foreign fighters" from various geographical areas, including from Western Europe (UK, France, Germany, Belgium, and the Netherlands). Terrorist networks cause a significant number of individuals, often young people, to leave their communities and travel to conflict zones, recruitment and radicalization being carried out with an increasing emphasis on the use of social networks and other digital channels.

On the other hand, a specificity of current terrorism is the presence in terrorist acts of "lone wolves" who, in their own name or under the coordination of established terrorist groups, engage in terrorist acts using explosive, chemical, biological or even radioactive materials.

In this context, Interpol has taken on an important role in the fight against terrorism globally. The institution successfully uses the bases containing information on biometric data, which are of major importance in identifying foreign terrorist fighters and preventing them from crossing borders, in their efforts to move to conflict zones. Through Interpol's IT network $^{13}$, police agencies or partner military structures can access and disseminate information on transnational terrorist networks and alert, in real time, their counterparts in third part countries. Biometric data can help accurately identify people who use a false identity, thus improving efforts to locate terrorists and conduct effective investigations. ${ }^{14}$

One of the approaches to terrorism, from the perspective of Interpol's activity, aims at cooperation between military structures and police structures, the institution being the first international organization to develop and implement a model for exchanging information between police and military structures. This course of action ensures that information from conflict areas are made available to the judiciary, in order to support their investigations and in the prosecution process. In addition, the military environment may disseminate relevant declassified information, collected from theaters of operations, to Interpol's National Central Offices, which processes the information in accordance with a well-established set of rules and then introduces the results into the databases. Information from Interpol databases contain information on approximately 48,700 foreign terrorist fighters, collected from areas of interest (border checkpoints, theaters of operations, conflict zones, and prisons). ${ }^{15}$

In order to streamline the activity, Interpol has developed and implemented two programs ${ }^{16}$ at regional level, in cooperation with partner organizations, focusing on training and building the capabilities of police forces to combat terrorism.

Another approach on terrorism, aims to interrupt the flow of funding, as an essential element for obstructing and reducing the activity of the organizations involved, being well known that the main sources of terrorist financing are as it follows. Therefore, the sources are kidnappings to obtain a ransom; interested use of non-profit organizations; illicit trade in

\footnotetext{
${ }^{13}$ The institution has created a program called "Project First" which aims to improve the identification of terrorists and their affiliates, by using the latest technology in digital image processing and facial recognition.

${ }^{14}$ Interpol, Identifying terrorist suspects, available at https://www.interpol.int/Crimes/Terrorism/Identifyingterrorist-suspects, accessed on 20.06.2020.

15 Interpol, Preventing terrorist travel, available at https://www.interpol.int/Crimes/Terrorism/Preventingterrorist-travel, accessed on 21.06.2020.

${ }^{16}$ The Scorpius Project and the Trace Project.
} 
digital goods and currencies; donations from financially powerful entities that embrace the ideology of terrorist groups; funds obtained from arms or drug trafficking etc. ${ }^{17}$

Such activities carries out through the relationship between specific institutions with ${ }^{18}$ a strategic role in developing policies in the field, but also through cooperation between institutions that manage information such as financial institutions and national police institutions. In order to encourage the exchange of information, the systematic inclusion of financial information related to the activities of terrorist groups in Interpol alerts having an essential role. ${ }^{19}$

In view of the alarming increase in the number of bombings using explosives and chemical or bacteriological substances, which endanger public safety and can have a severe impact on the economic and political stability of states, Interpol has been actively involved in preparing and supporting member states ${ }^{20}$, to specialize personnel in preventing and providing a relevant response to such attacks.

On the other hand, Interpol, through the Bioterrorism Prevention Unit, is concerned with the prevention and operational response to any form of action limited to bioterrorism, as part of a global security strategy, cooperating in this regard, at international and regional level, with national law enforcement agencies, health institutions and academia. ${ }^{21}$ At the same time, Interpol has concluded a large number of partnerships with institutions ${ }^{22}$ involved in combating terrorist actions of a chemical, radiological or nuclear nature.

In the context of Interpol's work, the United Nations Security Council has adopted a number of resolutions recognizing the institution's global role in combating terrorism. To streamline the fight against terrorism, Interpol and the Executive Board of the United Nations Counterterrorism Committee and the United Nations Office on Drugs and Crime have reached agreements, the activity being focused on combating organized crime and terrorism. ${ }^{23}$

\subsection{Measures taken at the level of the N.A.T.O.}

One of the objectives of the North Atlantic Treaty Organization (NATO) is to protect the civilian population, by developing the modern technological capabilities of the military component, against terrorist attacks, thus, the „Defense Against Terrorism Program of Work", known also as DAT POW, has been implemented. NATO ${ }^{24}$ approved the program, at

\footnotetext{
${ }^{17}$ Interpol, Tracing terrorist finances, available at https://www.interpol.int/Crimes/Terrorism/Tracing-terroristfinances, accessed on 21.06.2020.

${ }^{18}$ Financial Action Task Force, Egmont Group, etc.

${ }^{19}$ Interpol, Tracing terrorist finances, available at https://www.interpol.int/Crimes/Terrorism/Tracing-terroristfinances, accessed on 21.06.2020.

${ }^{20}$ The Watchmaker project is a global initiative that provides specialized support to member countries, using Interpol's notification system to alert security institutions around the world on the matter of people using or manufacturing improvised explosive devices. Interpol's database contains approximately 38,750 entities associated with chemical, biological and improvised explosive devices.

21 Interpol, Bioterrorism, available at https://www.interpol.int/Crimes/Terrorism/Bioterrorism, accessed on 21.06.2020.

${ }^{22}$ Europol; UN Office on Drugs and Crime; League of Arab States; US Federal Bureau of Investigation; French National Higher Police School; British Department of Business; NATO; United Nations Office on Terrorism; World Health Organization.

23 Interpol, Terrorism, available at https://www.interpol.int/Crimes/Terrorism/Partnerships-against-terrorism. Accessed on 21.06.2020.

${ }^{24}$ The program developed on the principle of joint funding, through the contribution of NATO countries, for the development of projects aimed at developing technologies and developing effective measures necessary to ensure the security environment in the context of contemporary terrorism.
} 
its meeting in Turkey in 2004, aiming to strengthen the Organization's contribution to preventing and combating the terrorist scourge, by developing technical capabilities and human resources to support various military operations and to encourage international cooperation. A major milestone in the operationalisation of the program was the meeting of NATO leaders, in 2017, when it was agreed the need for the increased role of NATO in the international fight against terrorism. ${ }^{25}$

Among the objectives of the Program is the development an appropriate framework for the management of terrorist attacks, by training and developing the skills of personnel involved in combating actions against the terrorist phenomenon and identifying measures to improve the organization and coordination of such attacks. Given the importance of the critical maritime infrastructure, the Program has developed tools for collaboration between civilian and military representatives to ensure the security against attacks involving improvised explosive devices. In 2018, under the coordination of France, DAT POW contributed to the development of the multinational exercise „Cut Away”, which aimed to ensure port security. ${ }^{26}$

Another objective is the protection of the organization's military personnel and aims at initiatives to train and improve personnel to reduce their vulnerabilities and the technique used, for a better conduct of operations, regardless of the nature or magnitude of threats. These initiatives comprise attacks with portable systems on military and civilian aircraft; threats caused by the proliferation of weapons of mass destruction and defense against chemical, biological, radioactive and nuclear attacks; use of improvised explosive devices.

Through the measures adopted, NATO aims to prevent terrorist entities from acquiring and using chemical, biological, radioactive and nuclear (CBRN) materials, while ensuring the security of the population and territories of the Member States. In this regard, the CBRN Joint Defense Center of Excellence, located in Vyskov, Czech Republic, aims to create and improve resilience to such an attack, namely to provide expertise in the field and make it available to the command structure of NATO and allied forces in theaters of operations. $^{27}$

Another initiative aims to prevent threats posed by explosive devices and manage the consequences that may arise from the explosion of such devices. In this case, the objective is to improve the capabilities of the organization, by training and improving teams specializing in the detection of explosive materials and ensuring optimal management of the effects of a terrorist attack with explosive devices. DAT POW supports NATO exercises and tests, coordinated by the Center of Excellence located in Trencin, Slovakia. With regard to improvised explosive devices, NATO supports the combat, through the Center of Excellence in Combating Improvised Explosive Devices located in Madrid, Spain. The Center proposed technological solutions for the detection of improvised explosive devices, while evaluating the information obtained from the application of attack management solutions with such devices. ${ }^{28}$

DAT POW also undertook the development of capabilities covering staff training and technology development, in order to improve the early identification and targeting of an effective response to the key points of terrorist networks that pose a security threat, by implementing the concept of network involvement. In this sense, by creating the Center of

\footnotetext{
${ }^{25}$ NATO, Defense Against Terrorism Program of Work, available at https://www.nato.int/cps/en/natolive/topics_50313.htm, accessed on 21.06.2020

${ }^{26}$ NATO, Defense Against Terrorism...

${ }^{27}$ NATO, Defense Against Terrorism...

${ }^{28}$ NATO, Defense Against Terrorism...
} 
Excellence for HUMINT, located in Oradea, Romania, the tools used in the identification and early warning of terrorist activities developed in order to improve technical interoperability within the NATO community regarding HUMINT ${ }^{29}$ information sources. On the other hand, the aim was to develop technologies that use biometric information, covering all areas necessary to ensure full capabilities. Subsequent to this approach, the role and necessity of the Special Operations Forces, an important component in the Counter-Terrorism Program, is noted.

\section{PREVENTING AND COMBATING TERRORISM AT EUROPEAN LEVEL}

\subsection{Measures taken at EU level.}

The issue of the fight against terrorism has been one of the important concerns of the European Union (EU) institutions. The European Convention on the Suppression of Terrorism, adopted in 1977, amended by the Protocol to the Council of Europe Convention of 2003, sets out a number of obligations of the signatory states with regard to the actions that need to be taken in order to combat the crime of terrorism, as defined in previously adopted international treaties. The Convention lists offenses, which the parties undertake not to consider political offenses are offenses related to political offenses or as politically motivated offenses. Yet, considering them acts of terrorism if they consist of the following activities hijacking of aircrafts, kidnapping and hostage-taking, the use of explosive devices, grenades, missiles, letters or packages that consume explosive devices, if their use endangers the physical integrity, life or liberty of persons. ${ }^{30}$

In order to ensure that the premise of discrimination does not create, the Convention expressly provides that no rule thereof shall oblige a signatory party to extradite a person prosecuted on racial grounds, religion, nationality or political opinion. ${ }^{31}$

The main obligation contained in international treaties aimed at combating terrorism, which consequently also operates in the case of the European Convention on the Suppression of Terrorism, refers to the introduction of offenses defined in the treaties in domestic criminal law, sanctioning acts of terrorism by sentences reflecting the seriousness of the crime. States that take part to these Treaties also agree to establish universal jurisdiction over such offenses. That is, to take the necessary measures to give the courts a very wide jurisdiction over the offenses in question, including jurisdiction based on territoriality, the nationality of the offender and of the victims, or a jurisdiction based on the mere presence of a suspect on the territory of a state. ${ }^{32}$ At the same time, States Parties accept the obligation to extract any suspected offenders identified in their own territory, or to initiate criminal proceedings against them. In order to facilitate extradition, these treaties provide that criminal offenses classify as political offenses, as they will not be subject to the extradition procedure under international law. In order to be effective, the provisions have to base on a certain level of cooperation between States Parties, materialized in the adoption of actions that have the

\footnotetext{
${ }^{29}$ NATO, Network engagement, available at https://www.nato.int/cps/en/natolive/topics_50313.htm, accessed on 21.06.2020.

${ }^{30}$ Regional Cooperation Council, European Convention on the Suppression of Terrorism-1977, available at https://www.rcc.int/p-cve/docs/97/european-convention-on-the-suppression-of-terrorism-1977, accessed on 20.06.2020.

${ }^{31}$ Regional Cooperation Council, European Convention on the Suppression of Terrorism...

${ }^{32}$ Daniel O'Donnell, International treaties against terrorism and the use of terrorism during armed conflict and by armed forces, International Review of the Red Cross, Volume 8, no. 864, December, 2006, available at https://www.corteidh.or.cr/tablas/a21937.pdf, accessed on 21.06.2020.
} 
effect of preventing terrorist acts or in the investigation and prosecution of crimes limited to the terrorist phenomenon. ${ }^{33}$

The increase in the different forms of terrorism in the Middle East in the first years of this decade, with the involvement of a large number of foreign terrorist fighters from the European area, has brought the issues on the agenda of the Council of the European Union and the European Council. There were attempts to identify coherent directions of action that would constitute a pragmatic response to this threat. On the other hand, the scale and media effect of the terrorist attacks in Paris in January 2015 led the EU leadership to take concrete, prompt, response measures against terrorist groups. Thus, a month later, a debate held on how to combat this type of security threat and, through a joint declaration, the vectors to guide EU action in three directions outlined ensuring a climate of security for citizens, measures to prevent and combat radicalization, safeguard values, and ensure cooperation measures with international partners.

In view of the EU's legal concerns about countering the activities of „foreign fighters", of major importance consists the adoption on 22 November 2015 of the Additional Protocol to the Council of Europe Convention on the Prevention of Terrorism. The Additional Protocol signed by EU representatives, and The Council of Europe Convention on the Prevention of Terrorism, being adopted a decade ago (16 May 2005) in Warsaw.

Of particular importance are the steps taken in recent years by many EU countries to re-conceptualize the regulatory framework for preventing and combating terrorism, the most important changes referring to the ban on leaving the national territory of their own nationals, in order to engage in terrorist acts abroad (France, Belgium, Germany, Spain, and Italy).

One of the EU's approaches to the issue of terrorism was the establishment in January 2016 of the European Counter-Terrorism Center (ECTC). In the context in which Islamist terrorist organizations have changed their strategy on how they operate, their attention has also shifted to Western Europe, amid escalating conflicts in the Middle East and the involvement of European states in the global fight against terrorism. On the other hand, with the migration phenomenon that has characterized the last decade, a large number of members of various Islamist terrorist organizations have entered European territory, this state of affairs producing changes and generating new security challenges at the level of the continent. ${ }^{34}$

Designed as a central EU institution in the fight against terrorism, the Centre's activity is to: provide operational support at the request of any EU Member State for conducting investigations; combat the activities of members of terrorist organizations; ensure the exchange of experience and information on terrorist financing ${ }^{35}$; combat online terrorist propaganda and extremism; combat illicit trafficking in arms and ammunition; ensure international cooperation between institutions with responsibilities for preventing and combating the terrorist phenomenon. ${ }^{36}$

The ECTC's work bases on tools that have measured its effectiveness in the fight against Europol's terrorist networks, with the Center organizing teams of experienced specialists from EU Member States. Their main mission is to gather operational information

\footnotetext{
${ }^{33} \mathrm{O}$ 'Donnell, International treaties against terrorism...

${ }^{34}$ Cătălin, Peptan, Considerations regarding the security equation determined by the problematics of refugees in the middle east, Research and Science Today, Nr 1(19)/2020, 9-18

35 Through the Program for Tracking the Financing of Terrorist Organizations and the Financial Intelligence Unit.

${ }^{36}$ European Counter Terrorism Center, ECTC, A central hub of expertise working to provide an effective response to terrorism, available at https://www.europol.europa.eu/about-europol/european-counter-terrorismcentre-ectc, accessed on 22.06.2020.
} 


\section{RST}

from the judicial institutions of the Member States, as well as from third parties, and to draw up reports whose beneficiaries are senior European decision-makers, in order to develop effective counter-terrorism policies. ${ }^{37}$

As part of Europol's operations department, ECTC works closely with other Europol operational centers (the European Center for Combating Cybercrime and the European Center to Combat Immigrant Smuggling), as well as other important partners, such as Interpol and Euro just, for the efficient management of information on the evolution of the terrorist phenomenon.

\subsection{Measures taken at the level of the Organization for Security and Cooperation in Europe.}

Having the attributes of an international security institution and consisting of both European countries and other geographical coordinates (North America, Caucasus, Central Asia), the Organization for Security and Cooperation in Europe (OSCE) has undertaken the task of preventing conflicts, managing crisis situations and getting involved in post-conflict reconstruction on the European continent.

Compared to one of the fundamental dimensions of the OSCE's work, namely the issue of politico-military aspects of security in Europe, Member States concluded that the contemporary terrorist phenomenon is one of the most significant threats to peace, security, stability, human rights, social and economic development, in the OSCE area and beyond. In this sense, they proceeded to the implementation of effective measures to prevent and combat terrorism, in all its forms and manifestations. ${ }^{38}$

The organization makes a substantial contribution to counter-terrorism efforts, promoting a coordinated approach and in a spirit of cooperation at all levels (between national authorities, cooperation between states, cooperation with relevant international and regional organizations and, where appropriate, supports the creation of public-private partnerships between different state authorities and the private sector, civil society and the media), to combat terrorism. These efforts are guided by and supported the UN overall counter-terrorism strategy, as well as relevant UN Security Council resolutions.

Activities to combat terrorism undertaken at the OSCE level are subsequent to the following areas: promoting the implementation of the international legal framework for combating terrorism and streamlining international legal cooperation in criminal matters related to terrorist activities; combating the sources that generate violent extremism and radicalization in order to commit terrorist actions, through a multidimensional approach. In addition, preventing and combating terrorist financing activities; implementation of measures that have the effect of preventing the use of information systems for committing or supporting terrorist actions; promoting a climate of cooperation and dialogue on counterterrorism issues. In particular, through public-private partnerships between state authorities and the private sector, and between civil society representatives and the media, strengthening the effort at Member State level to implement the provisions of Resolution no. 1540 of the 2004 UN Security Council ${ }^{39}$ aimed at combating the proliferation of weapons of mass

\footnotetext{
${ }^{37}$ European Counter Terrorism Center, ECTC, A central hub of expertise working to provide an effective response to terrorism...

38 OSCE, Countering terrorism, available at https://www.osce.org/countering-terrorism, accessed on 22.06.2020.

${ }^{39}$ In 2004, the UN Security Council adopted Resolution 1540, which was the first international document aimed at addressing the global and integrated approach to the issue of weapons of mass destruction and related materiel, imposing strong obligations on Member States. preventing and discouraging various entities from
} 
destruction. Moreover, strengthening the security elements present in travel documents and, finally yet importantly, implementing measures to promote and protect fundamental human rights and freedoms in the context of measures to combat the terrorist phenomenon. ${ }^{40}$

\subsection{Measures undertaken by the Bern Club}

In the context of the escalation of the activities of terrorist organizations at international level but also at the level of the European area, during the 60's, the leaders of prominent European intelligence services have decided to establish the „Bern Club” as an informal association in which the strategic direction of the European intelligence services was discussed. Since its inception, European intelligence services have cooperated with Israeli partners in the Shin Bet and Mossad intelligence structures, as well as with the US Federal Bureau of Investigation. Intelligence services from the $27 \mathrm{EU}$ Member States are currently cooperating within the Berne Club to find ways to respond, from the intelligence agencies perspective, to security threats at European and international level. ${ }^{41}$

In order to streamline operational cooperation following terrorist threats, the Berne Club decided to set up the "Counter-Terrorism Group" (CTG) in 2001.A common intelligence system supports it, starting with 2016, using an operational platform common to the security structures of the EU Member States that offers the possibility of real-time dissemination of information on potential terrorist acts. The exchange of information mainly concerns the activity of terrorist organizations of Islamist origin, without neglecting the issue of other areas related to European security. In its efforts to counter terrorism at European level, the cooperation between Europol and the CTG in bilateral investigations is noteworthy. Europol's 2018 annual report highlights the level of cooperation between the two institutions, while highlighting participation in joint exercises with the Migrant Smuggling Center and Europol's Internet Content Dissemination Office. ${ }^{42}$

\section{CONCLUSIONS}

The evolution and manifestation of the terrorist phenomenon, globally, in recent decades, has highlighted the need for concerted action to combat it, both by international institutions involved in the fight against the phenomenon and by state entities whose societal life has been deeply marked by the harmful effects of terrorist acts. The amplification of the forms of manifestation of the terrorist phenomenon imposed the adaptation from a conceptual and operational point of view of the answer offered by the institutions with attributions in achieving security. The results obtained in the fight against this scourge, especially in the last decade, express the viability of the measures adopted, the current reality highlighting a relative blurring of the dynamics of terrorist attacks globally. The danger of terrorism is unpredictable and imminent, and can occur anytime and anywhere, thus, individuals are exploiting vulnerabilities of the factors that characterize social life or groups who seek to generate chaos and destabilize public order, by instilling fear and distrust among citizens.

accessing this range of resources. See https://lege5.ro/Gratuit/ge3danbtgq3q/decizia-nr-809-2017-in-spartzenulpunerii-in-aplicare-a-rezolutiei-1540-2004-a-consiliului-de-securitate-al -the-organization-of-the-united-nationsregarding-the-non-proliferation-of-weapons-of-destruction-in-mass-, accessed on 22.06.2020.

40 OSCE, Countering terrorism, available at https://www.osce.org/countering-terrorism, accessed on 22.06.2020.

41 Matthias Monroy, Secret documents: European domestic intelligence services networking worldwide, available at https://digit.site36.net/2020/03/04/secret-documents-european-domestic-intelligence-servicesnetworking-worldwide/\#more- 2325, accessed on 06.09.2020.

42 Jan, Jirat, The Club de Berne: a black box of growing intelligence cooperation, available at https://aboutintel.eu/the-club-de-berne/, accessed on 06.09.2020. 
Complementary to the global or regional institutional actions, which constitute the prerogative of the different security organizations presented in the previous chapters, we believe that the state should take measures. The measures mean to strengthen national counter-terrorism capacities, improve cooperation and exchange of information between competent authorities, identify and stop terrorist financing channels, develop and implement a national crisis management system. The measures mean identify and block terrorist channels and means of communication, review and tighten legislation on terrorism and organized crime, and, last but not least, to improve cooperation with external agencies. On the other hand, of major importance is the revision and tightening of legislation on money laundering and terrorist financing, prioritizing the fight against terrorism by allocating financial, human and technological resources and analyzing the implications and damages caused to the national economy by terrorist phenomenon.

In the context in which terrorism has acquired a dynamic character, due to the diversification of the means of spreading fear, we believe that a series of gradual measures can prevent and diminish terrorism. The measures should aim at raising awareness of the danger by civil society and creating a culture of security at society level, being well known that, from the civil society standpoint, security also means as the need to ,preserve an acceptable lifestyle for citizens" ${ }^{23}$, which provides the premises to meet their needs, in a climate of individual and collective security. Thus, the citizen must become a ,generator" of state security, through an active position and partnership with security institutions, being aware of their role and necessity in modern society. As many of the actions subsequent to the terrorist phenomenon have ethnic or religious causes, we believe that an important role in easing the sources of conflict, which are the motivational germs of terrorist acts, belongs to non-governmental organizations, associations or minority representatives, through dialogue and negotiation, in order to identify and resolve problematic issues.

In conclusion, we appreciate that the security culture represents a fundamental dimension of education, seen as a primary way of an evolving society in the context of transformations in all fields, but also as a vector for enhancing and maximizing the power of any state in the architecture of the globalized world.

Nowadays it became a truism to say that prevention is much more effective than counteracting the destructive effects of terrorist actions.

\footnotetext{
${ }^{43}$ Approaches of the National Defense College, Canada, (1991), respectively of Ole Weaver, (1993). See Cristian, Troncotă, Security Studies, „Lucian Blaga” University of Sibiu, 2008, p. 6, Apud Nicu Sava, Security Studies, (Romanian Center for Regional Studies, Bucharest, 2005), 18-19.
} 


\section{REFERENCES}

1. Butnariu, Adrian, Consideration on the evolution of terrorism in Europe, Dissertation, Faculty of political Sciences, philosophy and Communication Sciences, West University of Timişoara, 2020.

2. Jirat, Jan, The Club de Berne: a black box of growing intelligence cooperation, disponibil la https://aboutintel.eu/the-club-de-berne/.

3. O'Donnell, Daniel, International treaties against terrorism and the use of terrorism during armed conflict and by armed forces, International Review of the Red Cross, Volumul 8, nr. 864, Decembrie 2006, disponibil la https://www.corteidh.or.cr/tablas/a21937.pdf.

4. Monroy, Matthias, Secret documents: European domestic intelligence services networking worldwide, disponibil la https://digit.site36.net/2020/03/04/secret-documents-european-domestic-intelligenceservices-networking-worldwide/\#more-2325.

5. Peptan, Cătălin, Terrorism-Security threat in the context of globalization, Annals of the „Constantin Brâncuși” of Targu-Jiu, Letter and Social Science, Series 1/2019.

6. Peptan, Cătălin, Considerations regarding the security equation determined by the problematics of refugees in the middle east, Research and Science Today, Nr 1(19)/2020.

7. Ruperez, Javier, The United Nations in the fight against terrorism, disponibil la https://www.un.org/sc/ctc/wp-content/uploads/2017/01/2006_01_26_cted_lecture.pdf.

8. Sava, Nicu, Studii de securitate, Centrul Român de Studii Regionale, București, 2005

9. Troncotă, Cristian, Studii de securitate, Universitatea „Lucian Blaga” Sibiu, 2008.

10. https://aviation-safety.net/database/record.php?id=19890919-1.

11. https://www.europol.europa.eu/about-europol/european-counter-terrorism-centre-ectc.

12. https://www.interpol.int/Crimes/Terrorism/Bioterrorism.

13. https://www.interpol.int/Crimes/Terrorism/Identifying-terrorist-suspects.

14. https://www.interpol.int/Crimes/Terrorism/Preventing-terrorist-travel.

15. https://www.interpol.int/Crimes/Terrorism/Partnerships-against-terrorism.

16. https://www.interpol.int/Crimes/Terrorism/Tracing-terrorist-finances.

17. http://mae.ro/sites/default/files/file/userfiles/file/pdf/Sanctiuni\%20in\%20vigoare/2010_08_Al\%20Qaed a,\%20Usama\%20bin\%20Laden\%20si\%20Talibanii.

18. https://www.nato.int/cps/en/natolive/topics_50313.htm, NATO, Defenseagainst Terrorism Programme of Work.

19. https://www.nato.int/cps/en/natolive/topics_50313.htm, NATO, Network engagement.

20. https://www.corteidh.or.cr/tablas/a21937.pdf.

21. https://www.osce.org/countering-terrorism.

22. https://www.history.com/this-day-in-history/pan-am-flight-103-explodes-over-scotland.

23. https://www.rcc.int/p-cve/docs/97/european-convention-on-the-suppression-of-terrorism-1977.

24. https://lege5.ro/Gratuit/ge3danbtgq3q/decizia-nr-809-2017-in-sprijinul-punerii-in-aplicare-a-rezolutiei1540-2004-a-consiliului-de-securitate-al-organizatiei-natiunilor-unite-cu-privire-la-neproliferareaarmelor-de-distrugere-in-masa-si-a.

25. https://www.sri.ro/fisiere/studii/cadrullegislativ.pdf. 